\title{
Museums Connect: Teaching Public History through Transnational Museum Partnerships
}

\author{
RICHARD J.W. HARKER
}

$\mathrm{T}$

Thrust into an exciting transnational collaboration in the summer of 2011 upon assuming my job as Education and Outreach Manager at the Museum of History and Holocaust Education at Kennesaw State University, I and other colleagues proceeded to facilitate a shared exploration with undergraduate students of what it means to be a

Muslim in both the American South and Morocco.' One of the results of this year-long Museums Connect project (2011-2012) - an online exhibition - built on the oral histories produced by an earlier Museums Connect grant between the two museums (2009-2010). The exhibition stands testament to the hard work of many staff, faculty and students throughout a yearlong project that wrestled with cultural and language barriers, technological difficulties that made communication a constant

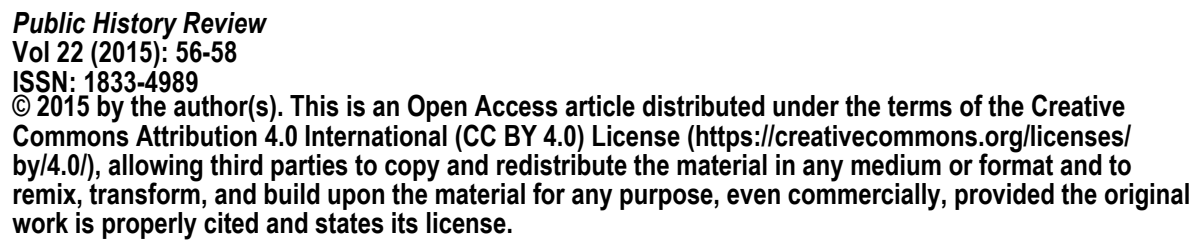


challenge and competing ideas about the fundamental nature of interpretation and representation. However, these two projects should not be viewed as uncritical successes.

Through a close analysis of the projects' activities and reflections from participating museum staff, university faculty and participating students, these projects have proven to be beneficial to both faculty and students engaged in the development of practical public history skills and their implementation in high-stakes real-world environments. Yet, it is also clear that this transnational partnership presented power imbalances around professional training and expertise as well as challenges to long-term sustainability. These issues need to be understood and considered carefully from the outset to ensure as equal and successful a collaborative partnership as possible.

Museums Connect is funded by the US Department of State's (DOS) Bureau of Educational and Cultural Exchanges and administered by the American Alliance of Museums (AAM) and sponsors partnerships between museums in the United States and a partner museum abroad. It is one of a myriad of DOS exchange programs that collectively engage with 50,000 participants annually. And these programs developed out of the emergence of educational and cultural exchanges as an important part of US public diplomacy during and immediately after World War II. ${ }^{2}$ However, unlike other international exchange programs funded by DOS, and exchanges conducted between academic public history programs, Museums Connect is both the only program focused exclusively on museums and also attempts to engage the museums' and their communities, often school aged or college students, in collaborative transnational projects. ${ }^{3}$ This program thus provides one model for studying the teaching of public history internationally given the DOS' stated goal of focusing on 'local community engagement.'

\section{'CREATING COMmUNity CollaboRation' AND 'IDENTITIES': UNDERSTANDING ISLAM IN A CROSS-Cultural Context}

Between 2008 and 2012 the Museum of History and Holocaust Education (MHHE) at Kennesaw State University (KSU) in Georgia and the Ben M'sik Community Museum (BMCM) at University Hassan II in Casablanca, Morocco, engaged in two Museums Connect projects. The grants continued a pre-existing partnership between the two museums that began when the MHHE director Dr Catherine Lewis and other KSU faculty and staff played an active role in the founding of the BMCM in 2005. In addition to the Museums Connect program's stated goals of engaging with new communities both grant projects were designed to 
engage university students and museum staff as their primary audiences.

The application for the first Museums Connect grant 'Creating Community Collaboration' stated that teams of undergraduate from the American Studies and English departments at University Hassan II and the History and American Studies departments at KSU would engage in a comparative oral history project. ${ }^{6}$ This was designed to created 'extended conversations' that were intended to 'change the perspectives of the participants, dispel stereotypes and correct misinformation, and remind us that trust comes slowly' and lead to follow-up programs to create dialogue around what was learned from the oral histories. ${ }^{2}$ At the center of this grant proposal was the intention of both museums to engage in a process of 'shared inquiry': a collaborative, transnational public history project that sought the education of their respective university students through the practical experience of learning about and conducting community oral history interviews. ${ }^{8}$ Similarly, this idea was extended when the two museums were offered the opportunity to apply for a one-off 'continuing' Museums Connect grant. This second grant engaged the university students in the development of an online exhibit that utilized, among other components, the first grant's oral histories. Two of the three stated outcomes in the second grant proposal also focused on the students as the primary audience: 'Student participants will master theory and practice of exhibition development' and 'Student participants will develop a broader knowledge of one another's cultures.'

The various written and oral reflections of the faculty, staff and students who participated in these projects underscore a high level of personal and institutional satisfaction with the projects. From the KSU Public History Program's perspective, Dr, Jennifer Dickey - the program's coordinator - later glowingly reflected that the grants provided the students with a range of new transnational public history skills in excess of a more traditional internship: 'Although the acquisition of tangible skills was undoubtedly beneficial to the students, the opportunity to work with the faculty and students of the BMCM and their community in Morocco and in Washington, D.C. was perhaps the most thrilling part of the project.' ${ }^{\prime 10}$ Many of the students who participated in the project also cited working in a transnational environment as a particularly interesting and powerful way for them to engage in public history. Robyn Gagne, while remembering the visit of the American students to Morocco, recalled how her American public history sensibilities were challenged and expanded upon while visiting Moroccan museums in December 2011. 'It was so interesting how 
museums are curated differently in Morocco... there would be a case with some artifacts, a label written in French and Arabic with what the object was, and, if you were lucky, a date. There was very little interpretation.'"

The projects, however, not only served the purpose of enhancing the KSU Public History Program. In addition to the rare opportunities to travel to the US, the Moroccan students and faculty also developed skills as public historians with the oral history and exhibition development training sessions held for both groups of students concurrently by Skype." Chaimaa Zamat, one of University Hassan II students selected to work on the BMCM team reflected after the project: 'I have... had the chance to get involved in many tasks, like doing transcription and translation of people's testimonies recorded by the previous team. These were the citizens' opinions about their daily life in the neighborhood, society, Morocco, and even the United States of America. ${ }^{13}$ Another BMCM student, Soumaya Ezzahouani, reflected on the skills that she developed when she wrote: 'I have learnt so many new things about museums and good online exhibits. The workshops were very fruitful. ${ }^{\prime}{ }^{4}$ However, while also learning tangible skills the Moroccan students' post-project reflections highlight a significant change in thinking about the potential role of museums in Moroccan civic life. Poignantly Chaimaa Zamat reflected, for example,'[N]ow I know that a museum is not only a place which displays artifacts to be shown to tourists and the elites but rather an open place for the public. It serves the community living in this neighborhood.'

In addition to developing new public history theory and practice, the projects also challenged the American students' perspective about America's role in the world and encouraged empathy and understanding of their Muslim counterparts. ${ }^{16}$ This evidence, and the observations recorded by the students in their journals and on the project blog, thus corroborated the DOS' sponsorship of this program as a vehicle of cultural diplomacy. KSU student Matt Scott, for example, who had never left the U.S. before traveling to Morocco during the second 'continuing' grant; observed at the time: 'I was fortunate enough to be able to go to Morocco... and that completely rocked my world in terms of how I even conceptualized the project that we are doing. ${ }^{\prime}{ }^{17} \mathrm{~A}$ follow-up survey conducted with the Moroccan students in 2015 also suggested their involvement in the Museums Connect continued to shape the way they thought of themselves, their own identities and what it means to be a Muslim. Ismail Chaki, for example, reflected: 'I can say 
for myself that the project had an impact on me... [it] gave me a certain maturity in the way I handled my life. ${ }^{\prime}$

The significance and success of working collaboratively with other students from different a country should also not be underestimated. Deep and long-lasting friendships - what the DOS calls people-to-people diplomacy - were forged between Moroccan and American students during the projects. Gagne later reflected that working side-by-side with the Moroccan students during the two travel portions of the 'Identities' grant built deep friendships: 'We all felt like we had made good friends, and it was hard to part... As I hugged Zineb, I told her that this was not goodbye but we would see each other again. Zineb and I cried together. '19

This sentiment was echoed by all of the project facilitators who independently cited the two projects ability to create deep personal bonds as a significant highlight of the grants. So profuse was her praise for this element of the grant, that Lewis reflected that it was in the process of working together - and not necessarily the product that was developed - that the students learned the most and developed deep personal and professional relationships. She suggested, 'I don't think the website for the second grant is the thing to celebrate. I think it was the process. ${ }^{20}$

\section{A SHARED INQUIRY?}

In applying for the grants the MHHE and BMCM framed them as collaborative endeavors that engaged with recent literature in the fields of museum studies and public history that explored the implications of a shared intellectual authority." In so doing, both projects sought to share the process and creation of product between the two museums, their respective university communities and the wider community. Despite the aforementioned successes of these endeavors, however, both of these grants also highlighted the challenges of engaging in collaborative endeavors across international boundaries.

The challenge of engaging in truly collaborative projects was most acute because the expertise to conduct oral histories and then utilize them for an online exhibition resided with the KSU and MHHE staff and faculty. The MHHE has a particularly close relationship with KSU's undergraduate Public History program. Dickey, the Public History coordinator and Assistant Professor of History at KSU, was on the project team for both grants, and Lewis, who is the MHHE Executive Director, previously directed the Public History program at KSU and also holds a faculty position in the history department at KSU. Moreover, Dr Julia Brock, with a PhD in public history, was hired by the 
MHHE to be the project coordinator for the second grant, 'Identities: Understanding Islam in a Cross-Cultural Context', in September 2011.2

Although both museums were new to transnational collaborative projects, the presence of these three trained public historians at the MHHE and the presence of activities that are embedded in the disciplinary practices of American academic public history contrasted with the training of the faculty and staff at the BMCM and University Hassan II..$^{23}$ The students and faculty that volunteered for the project in Morocco were drawn from the English and History departments, reflecting the reality that work of the project would be conducted in English. And these students' volunteerism reflected a significant personal commitment, as Moroccan higher education neither has internships nor reward students for extra-curricula activities. ${ }^{24}$ Moreover, Samir El Azhar, the Director of the BMCM - officially called the museum's 'coordinator' - is also a member of the American Studies faculty and possessed no formal public history or museological training prior to taking control of the BMCM in 2006. Despite El Azhar's successful negotiation of the local elements of the projects and advocacy for them within his university and local community, his account of the two projects as the 'turning point in my professional life... It has opened my eyes to the fact that museums should not be mere places where artifacts are displayed. They should be dynamic institutions', suggest that the public history education provided to the students was also beneficial to him. ${ }^{25}$

These educational and skill imbalances, while neither detrimental to the success of the project nor diminishing the work of El Azhar in directing the Moroccan half of the project by himself, had the effect of placing the onus of providing 'public history training' in oral history and exhibition development skills and methodology for both groups of students in the hands of the KSU and MHHE staff and faculty. Lewis, who was the driving force behind both grants, freely acknowledged the professional power differential that existed with her Moroccan colleague despite their deep friendship, recalling that she led the project activities because of a professional 'power imbalance, because Samir had never done this. ${ }^{26}$ Dickey also acknowledged that with the best possible intentions the American professionals attempted to 'train' their Moroccan colleague, recalling that throughout the projects they tried 'to help him [El Azhar] get up to speed in terms of being a museum

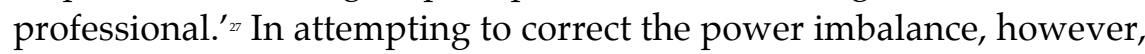
the MHHE faculty and staff were inadvertently acting out a form of 
intellectual colonialism by teaching American public history and museum studies to their Moroccan counterpart. ${ }^{2 s}$

The reality of these power relationships was also realized in Morocco. Members of the faculty at University Hassan II levied the charge of 'intellectual colonialism' at the projects and the partnership between the BMCM and MHHE. El Azhar explained that, 'In the Arab and Muslim world, people are suspicious of programs sponsored or financed by the US and Western countries.' He concluded, however, that his belief in the nature of the collaboration and the relationships between the two museums made this criticism irrelevant: 'Convinced of the objectives of the [Museums Connect] projects, we did not pay attention to criticism. ${ }^{29}$

The tight timelines of the projects, moreover, and cultural differences ensured that this teaching, while based in American public history practices, was truncated, practically oriented and adapted for the transnational context and thus not solely a manifestation of American intellectual colonialism. Lewis recalled: 'I taught them [the Moroccan students] the very basic issues of oral history... But we couldn't get too philosophical about it. We had to be just really, really practical: here is how you write questions, here's the technology, here's a consent form.' ${ }^{30}$ The process of teaching oral history during the first grant, therefore, was not simply a reproduction of the American classroom.

The imbalance in power between the two sides of these collaborative projects also manifested during the second grant when the BMCM team met the MHHE team in Washington DC, for exhibit development meetings in addition to sightseeing and shared activities. Sitting around a conference table in the AAM offices in March 2012 students, staff and faculty frustratingly and tensely debated the style, content and symbolism of the 'Identities: Understanding Islam in a Cross-Cultural Context' exhibit logo and graphic design. Because the logo would be the single graphic element that represented the entire year spent studying identity in Morocco and America, its importance was well understood by all participants. Dickey later described the impasse and heightened tensions when she recalled: 'Both teams brought design suggestions to the table, and it quickly became obvious that there was a wide gap between the two sides in terms of design aesthetics - shapes and colors had vastly different meanings for each team. ${ }^{3 i}$ El Azhar recalled that the impasse occurred because of the two teams possessed fundamentally contrasting cultural perspectives and sensibilities. And he generously suggested that this tense phase of exhibit development was negotiated because of 'how honest the two teams were, and the matter was discussed in a very calm, serious, serene way.' ${ }^{\prime z}$ Brock, the project 
coordinator, however, reflected with unease about the power dynamics at play when the MHHE's designer was employed to merge the different ideas: 'This made some participants rightly uncomfortable - how much did the logo really reflect a compromise? Though all participants agreed on the final version, were our Moroccan partners eventually silenced because of our executive decision to pass the logo to the MHHE designer?'ss

The power differential and skill gap, however, not only emanated from the faculty's respective training and professional experience; the two countries had radically different museological contexts. In contrast to the civic and educational roles of American museums that have evolved to locate these institutions at the center of American public life, Moroccan museums serve the role of collecting money from tourists with little focus on Moroccan audiences or communities. ${ }^{34}$ Katarzyna Pieprzak, a scholar of Moroccan museology, argues that 'state-run museums appear stuck in an intellectual mission that excludes the public and public life.' This has resulted, she argues, in 'the anemic presence of museums as resources for collective memory, and to their absence as central architectures working to promote access to and participation in Moroccan cultures and history. ${ }^{33}$

The Moroccan museological context was also deplored by El Azhar, placing the Moroccan context explicitly in comparison with that of the US and other so-called 'developed' museologies, who argued that '[v]ery few Moroccan museums meet even the most basic standards of museology common to North American, Scandinavian, European, or Asian institutions. ${ }^{\prime \prime}$ Although some of this rhetoric may have been used to differentiate and elevate the significance of the new type of community museum the Ben M'sik Community Museum is striving to be, the larger Moroccan milieu that does not value museums as educational institutions further exacerbated the problem of the professional and expertise knowledge gap between the MHHE and BMCM. This point was noted by Dickey, who recalled wrestling with these dynamics throughout the grants: 'I'm not sure what the answer is... [Museums Connect] is an inherently imperialistic undertaking in a way because of nature of the way that it's structured: the source of the money and the source of the expertise. ${ }^{37}$

\section{MISAPPROPRIATIONS OR ADAPTATIONS?}

Despite the power imbalances, the Moroccan participants actively negotiated and adapted the pedagogical activities to their local context. Although many of the project activities occurred as proposed, the oral 
history project during 'Creating Community Collaborations' highlighted one example of how grant activities were negotiated and re-imagined to meet the needs of the BMCM and its community. The grant set aside money for both museum teams to pay their oral history narrators to thank them for sharing their histories. ${ }^{38}$ The way this money was actually spent, however, and the way this situation has been subsequently understood and re-told reflect the spontaneous and culturally specific ways that project components can be altered and changed when practiced by two different museums and their students across thousands of miles.

The BMCM spent the oral history money on computers for a local school rather than give it to the narrators as originally planned. Knowing that the conditions of the grant as agreed to in the signed Implementation Agreement were broken, the MHHE and KSU staff was concerned that despite the BMCM's best intentions US government money had been misappropriated, thereby potentially putting the MHHE at serious legal risk as the grant's 'lead museum'. Lewis, recalling genuine anxiety of legal recriminations as the first grant's director, remembered: '[This] proved a big problem because it was not part of the grant, and it didn't help the grant. ${ }^{{ }^{3}}$ Dickey also acknowledged the benefit of the BMCM's actions but highlighted the governing American grant culture of Museums Connect that understands the acceptance of grant funding - especially from the federal government - as contractual, noting the consequently serious impact of changing the way that money is spent in such a project."

El Azhar, however, interpreted this event differently. When asked about this phase of the project he explained that after learning that Moroccan law prohibits public institutions gifting cash to the public, and having informed the narrators that the money could not be given to them, a long debate occurred over several meetings that eventually led to the decision to buy computers for a local elementary school." Differing significantly from Lewis and Dickey's interpretations of these actions, El Azhar subsequently reflected on the 'feeling of pride' generated, recalling: 'I believe this action is far better than giving a meager sum of money to some individuals who could have spent it on futile things.' ${ }^{\prime 2}$

A third interpretation of this situation was offered by Mary Jeffers, Foreign Service Officer at the US Embassy in Morocco at the time of the Museums Connect projects, who suggested that the actions of the BMCM were in keeping with the types of situations the DOS hopes will come out of cultural diplomacy programs like Museums Connect. Speaking from her perspective as a State Department employee working on the 
ground in Morocco, she likened the project to the story of the 'stone soup' and recalled:

It was so impressive... it was also an outgrowth of this kind of self-empowering feeling that I think that the museum project helped to encourage. I don't want to say that it, the museum project, generated the entire community sense of wanting to do something in the community. But I think that it played a role."

The multiple interpretations of this part of the oral history project highlight one way that the American-driven public history project was negotiated and adopted within the local contexts by the BMCM, and the multiple ways, regardless of power differentials and imbalances that these activities - planned and unplanned - were negotiated and then later interpreted.

\section{CONCLUSION}

In a book published in 2012 in Morocco to accompany the 'Identities: Understanding Islam in a Cross-Cultural Context' project, I optimistically reflected from my perspective as a project facilitator that the students involved 'not only developed the curatorial skills necessary to create an online exhibit, but... also developed a deeper understanding of Islam and what it means to be a Muslim both in the American South, and also in Morocco.' ${ }^{\prime 4}$ Even allowing for excessive praise of a grant that provided us with nearly $\$ 150,000$ to enact innovative and exciting museum partnerships, support the museums and universities' pedagogical offerings and also helped their -and my - tenure and promotion (faculty) and career (student and staff) possibilities, the reflections of those involved in the two Museums Connect grants between the MHHE and the BMCM highlight that this program allowed for the development of skills by the two student teams. Moreover, the students' reflections emphasize the role that these projects played in encouraging greater cultural awareness in addition to a greater understanding of the impact that community work in different communities has on the public history projects.

The Museums Connect projects between the MHHE and BMCM, however, also emphasized several challenges of teaching public history transnationally when one partner possesses significantly more professional training and works within a museological context that values the museum as an educational space. The potential for these kinds of uneven distributions of resources and training is embedded in a 
program funded by the American government and administered by the American Alliance of Museums and features American museums as the 'lead museum' in a transnational partnership. However, this article also argues that it is naïve to assume that American activities and ideas are passively absorbed abroad and regardless of larger power differentials, activities and ideas will be negotiated on a local level.

Understanding and acknowledging potential power dynamics and being self-critical and reflective is vital to ensure that as equal a partnership as possible can be formed from the outset. The field of oral history and cross-cultural interviews and the power balances that are frequently discussed may be one area of scholarship that public historians consult for guidance here. The work of Belinda Bozzoli and Susan K. Burton, for example, and their challenge to reflect on our own subjectivities, processes and positions of power - including discursive power and language - when working in a cross-cultural context can be instructive in considering how to confront power differentials such as those emerging from the transnational Museums Connect program. ${ }^{45}$

\section{ENDNOTES}

' The term 'transnational' is used over 'international' to reflect the exchanges and connections that are central to Museums Connect. On this debate, see Ian Tyrrell, 'American

Exceptionalism in an Age of International History', The American Historical Review, vol 96, no 4, 1991, pp1031-1055 and Michael McGerr, 'The Price of the New "Transnational History",' The American Historical Review, vol 96, no 4, 1991, pp1056-1067.

United States Department of State Bureau of Educational and Cultural Affairs, 2015,

Celebrating 75 Years of International Exchange Programs, 1940-2015 (Online). Available: http: / / exchanges.state.gov/ files/75th/index.html (Accessed 26 September 2015). The Panel on International Information, Education, and Cultural Relations, International Information Education and Cultural Relations: Recommendations for the Future, Center for Strategic and International Studies, Washington DC, 1975, p1.

See for example the partnership between Princeton, University of Massachusetts-Amherst, and Shanghai Normal University: Richard Anderson, 'What I learned on my (public history) summer vacation', (Online). Available at: http: / / publichistorycommons.org/public-historysummer-vacation/ (Accessed 25 September 2015).

- United States Department of State Bureau of Educational and Cultural Affairs, 2015, Museums Connect (Online). Available: http:/ / exchanges.state.gov/non-us/program/museumsconnect (Accessed 13 May 2015).

Museum of History and Holocaust Education and Ben M'sik Community Museum, 'Narrative, Timeline, Budget, MCCA 2008-2010 Creating Community Collaboration Narrative, Timeline, Budget', American Alliance of Museum Archive, p3.

ibid, p4.

Museum of History and Holocaust Education and Ben M'sik Community Museum, 'Executive Summary, MCCA 2008-2010 Creating Community Collaboration', American Alliance of Museum Archive, p1.

' Katharine T. Corbett and Howard S. Miller, 'A Shared Inquiry into Shared Inquiry', The Public Historian, vol 28, no 1, 2006, pp15-38.

- Museum of History and Holocaust Education and Ben M'sik Community Museum,

'Background MCCA Continuing Grants Proposal: Identities: Understanding Islam in a Cross Cultural Context', American Alliance of Museums Archives, p6.

${ }^{10}$ Jennifer Dickey, 'The World is Our Classroom', in Julia Brock, Jennifer Dickey, Catherine M. Lewis and Samir El Azhar, 'Exploring Identities', The Public Historian, vol 34, no 4, 2012, p19. 


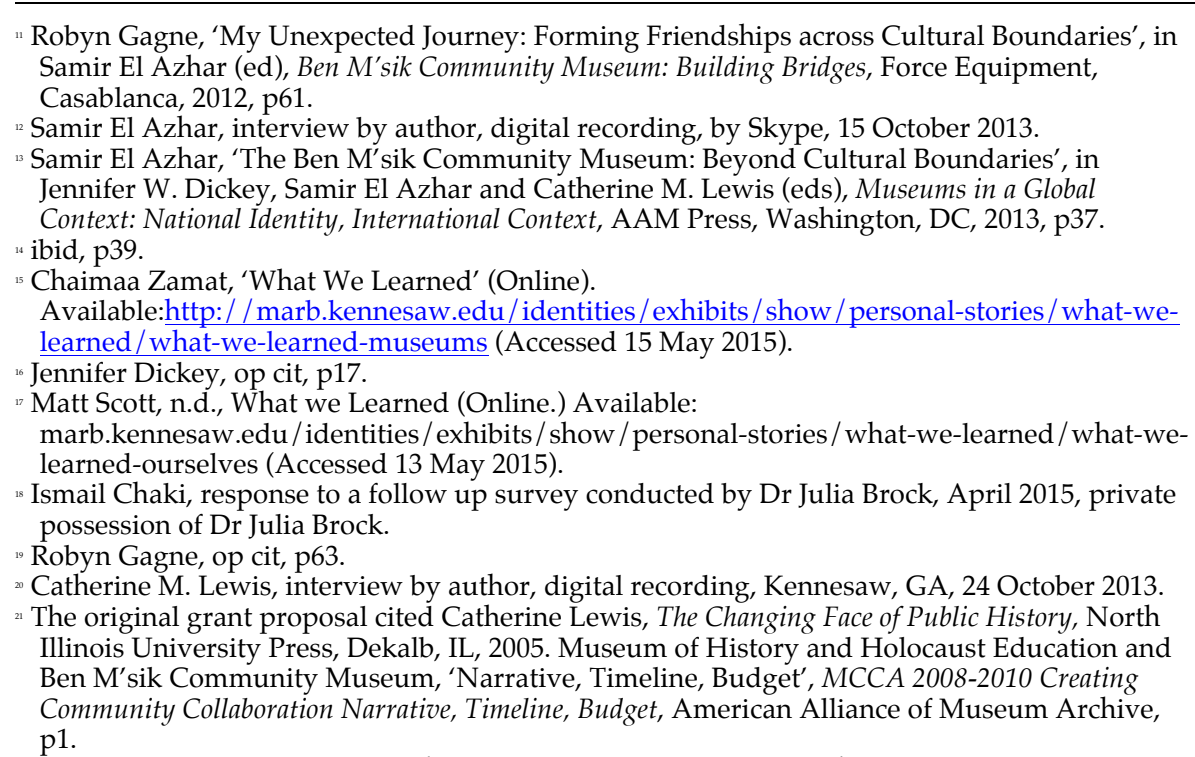

" Julia Brock, Jennifer Dickey, Catherine M. Lewis, and Samir El Azhar, 'Exploring Identities', The Public Historian, vol 34, no 4, 2012, pp9-29.

${ }^{2}$ For concise histories of Public History as an academic discipline in the United States and Canada see The National Council on Public History, n.d.,'What is Public History?' (Online.) Available: http:/ / ncph.org/cms / what-is-public-history / (Accessed 16 May 2015.) See also Hilda Kean and Paul Ashton, 'Introduction', in Paul Ashton and Hilda Kean (eds), Public History and Heritage Today: People and their Pasts, Palgrave Macmillan, Basingstoke, 2012, pp120.

${ }^{2}$ Samir El Azhar, e-mail message to author, 11 June 2015.

¿Samir El Azhar, op cit, p37.

${ }^{2}$ Catherine M. Lewis, interview by author.

" Jennifer W. Dickey, interview by author, digital recording, Kennesaw, GA, 30 October 2013.

* Elif M Gokcigdem and Michelle M. Seaters, 'Building Local and Global Cultural Connections and Creative Thinking Skills Trough an Exhibit of Islamic Arts for Children in Saudi Arabia', in Jennifer W. Dickey, Samir El Azhar and Catherine M. Lewis (eds), Museums in a Global Context: National Identity, International Context, AAM Press, Washington, DC, 2013, p168.

${ }^{*}$ Samir El Azhar, e-mail message to author, 11 June 2015.

${ }^{\infty}$ ibid.

"Jennifer Dickey, op cit, p19.

"Samir El Azhar, interview by author, digital recording by Skype, 15 October 2013.

sulia Brock, 'Managing International Public History Work', in Julia Brock, Jennifer Dickey, Catherine M. Lewis and Samir El Azhar, 'Exploring Identities', The Public Historian, vol 34, no 4, 2012, p27.

"Useful introductions to this include American Association of Museums, Mastering Civic Engagement: A Challenge to Museums, AAM Press, Washington DC, 2002 and more recently Gail Dexter Lord and Ngaire Blakenberg, Cities, Museums, and Soft Power, AAM Press, Washington DC, 2015. The vast gap in the two countries' museum cultures was also identified in interviews with projects facilitators.

${ }^{*}$ KatarzynaPieprzak, 'Participation as Patrimony: The Ben M'Sik Community Museum and the Importance of the Small Museum in Morocco', in Samir El Azhar (ed), Ben M'sik Community Museum: Building Bridges, Force Equipement, Casablanca, 2012, p12.

* Samir El Azhar, 'The Ben M'sik Community Museum: Beyond Cultural Boundaries', in Jennifer W. Dickey, Samir El Azhar and Catherine M. Lewis (eds), Museums in a Global Context: National Identity, International Context, AAM Press, Washington, DC, 2013, p29.

* Jennifer W. Dickey, interview by author.

Catherine M. Lewis, interview by author.

${ }^{\infty}$ ibid.

" Jennifer Dickey, written correspondence to author, 17 August 2015.

"Samir El Azhar, interview by author, digital recording by Skype, 15 October 2013.

"Samir El Azhar, e-mail message to author, 4 June 2015. 
* Mary Jeffers, interview by author, digital recording by phone, 31 January 2014.

"Richard Harker, 'Educating Against "Islamophobia": Creating an International Exhibit to

Counter Intolerance', in Samir El Azhar (ed), Ben M'sik Community Museum: Building Bridges,

Force Equipment, Casablanca, 2012, p44.

Belinda Bozzoli, 'Interviewing the Women of Phokeng', in Robert Perks and Alistair Thomson

(eds), The Oral History Reader, Routledge, New York, 2"ed, 2007, pp155-165 and Susan K.

Burton, 'Issues in Cross-Cultural Interviewing: Japanese Women in England', in Perks and

Thomson (eds), The Oral History Reader, pp166-176. 